\title{
Long-Term History of Vegetation and Fire in Pitch Pine-oak Forests on Cape Cod, Massachusetts
}

\section{Citation}

Parshall, T., Foster, D. R., Faison, E. K., MacDonald, D., Hansen, B. C. S. 2003. Long-term history of vegetation and fire in pitch pine-oak forests on Cape Cod, Massachusetts. Ecology 84: 736-738.

\section{Published Version}

10.1890/0012-9658(2003)084[0736:LTHOVA]2.0.C0;2

\section{Permanent link}

http://nrs.harvard.edu/urn-3:HUL.InstRepos:30663041

\section{Terms of Use}

This article was downloaded from Harvard University's DASH repository, and is made available under the terms and conditions applicable to Other Posted Material, as set forth at http:// nrs.harvard.edu/urn-3:HUL.InstRepos:dash.current.terms-of-use\#LAA

\section{Share Your Story}

The Harvard community has made this article openly available.

Please share how this access benefits you. Submit a story.

\section{Accessibility}




\title{
LONG-TERM HISTORY OF VEGETATION AND FIRE IN PITCH PINE-OAK FORESTS ON CAPE COD, MASSACHUSETTS
}

\author{
T. Parshall,${ }^{1,3}$ D. R. Foster,${ }^{1}$ E. Faison,${ }^{1}$ D. MacDonald,${ }^{1}$ and B. C. S. Hansen ${ }^{2}$ \\ ${ }^{1}$ Harvard Forest, Harvard University, P.O. Box 68, Petersham, Massachusetts 01366 USA \\ ${ }^{2}$ Limnological Research Center, University of Minnesota, Minneapolis, Minnesota 55455-0219 USA
}

\begin{abstract}
Human disturbance in northeastern North America over the past four centuries has led to dramatic change in vegetation composition and ecosystem processes, obscuring the influence of climate and edaphic factors on vegetation patterns. We use a paleoecological approach on Cape Cod, Massachusetts, to assess landscape-scale variation in pitch pine-oak vegetation and fire occurrence on the pre-European landscape and to determine changes resulting from European land use. Fossil pollen and charcoal preserved in seven lakes confirm a close link between landform and the pre-European distribution of vegetation. Pine forests, dominated by Pinus rigida, were closely associated with xeric outwash deposits, whereas oak-hardwood forests were associated with landforms having finer grained soils and variable topography. In general, fire was much more abundant on Cape Cod than most other areas in New England, but its occurrence varied geographically at two scales. On the western end of Cape Cod, fires were more prevalent in pine forests (outwash) than in oak-hardwood forests (moraines). In contrast, fires were less common on the narrow and north-south trending eastern Cape, perhaps because of physical limits on fire spread.
\end{abstract}

The most rapid and substantial changes during the past 2000 years were initiated by European settlement, which produced a vegetation mosaic that today is less clearly tied to landform. Quercus and other hardwood trees declined in abundance in the early settlement period in association with land clearance, whereas Pinus has increased, especially during the past century, through natural reforestation and planting of abandoned fields and pastures. An increase in fossil charcoal following European settlement suggests that fire occurrence has risen substantially as a result of forest clearance and other land uses, reaching levels greater than at any time over the past 2000 years. Although fire was undoubtedly used by Native Americans and may have been locally important, we find no clear evidence that humans extensively modified fire regimes or vegetation before European settlement. Instead, climate change over the past several thousand years and European land use over the past 300 years have been the most important agents of change on this landscape.

Key words: Cape Cod, Massachusetts (USA); charcoal; land use; paleoecology; pitch pine-oak forest; pollen.

\section{INTRODUCTION}

Human disturbance in northeastern North America over the past four centuries has directly altered the structure and composition of modern vegetation, as entire landscapes have experienced variable intensities of resource extraction, agricultural clearance, and reforestation (Cronin 1983, Williams 1989, Turner et al. 1990, Whitney 1994). Vegetation composition and pattern are also controlled by the frequency and intensity of natural disturbances (Pickett and White 1985, Foster et al. 1997, 1998a), and modern disturbance regimes are closely tied to human activities, as is clearly true of fire (Whelan 1995, Pyne et al. 1996). The result of these direct and indirect human impacts is vegetation

Manuscript received 9 October 2001; revised 9 July 2002; accepted 21 July 2002; final version received 15 August 2002. Corresponding Editor: S. T. Jackson.

${ }^{3}$ Present address: Kellogg Biological Station, 3700 East Gull Lake Drive, Hickory Corners, Michigan 49060 USA. E-mail:parshal4@kbs.msu.edu whose structure and composition may now be less tied to edaphic and climatic influences than in the past (White and Mladenoff 1994, Foster et al. 1998b).

In New England, the effects of European land use on both vegetation and fire have been substantial, especially along the coast where most of the earliest towns were first established (Dunwiddie and Adams 1995, Dunwiddie 2001, Eberhardt 2001). On Cape Cod, Massachusetts, the link between human history and fire was probably very strong, because fire has been an important component of this ecosystem in the past and the vegetation is dominated by Pinus rigida and Quercus spp., whose occurrence is closely linked to fire history (Little 1979, Winkler 1985, Patterson and Backman 1988). The extent and spatial distribution of fire on the pre-European landscape, the relationship of fire to vegetation pattern, and the effects of human actions on fire are all poorly understood on this landscape. Early historical observations of Cape Cod forest are limited to the immediate coast and differ in their details 


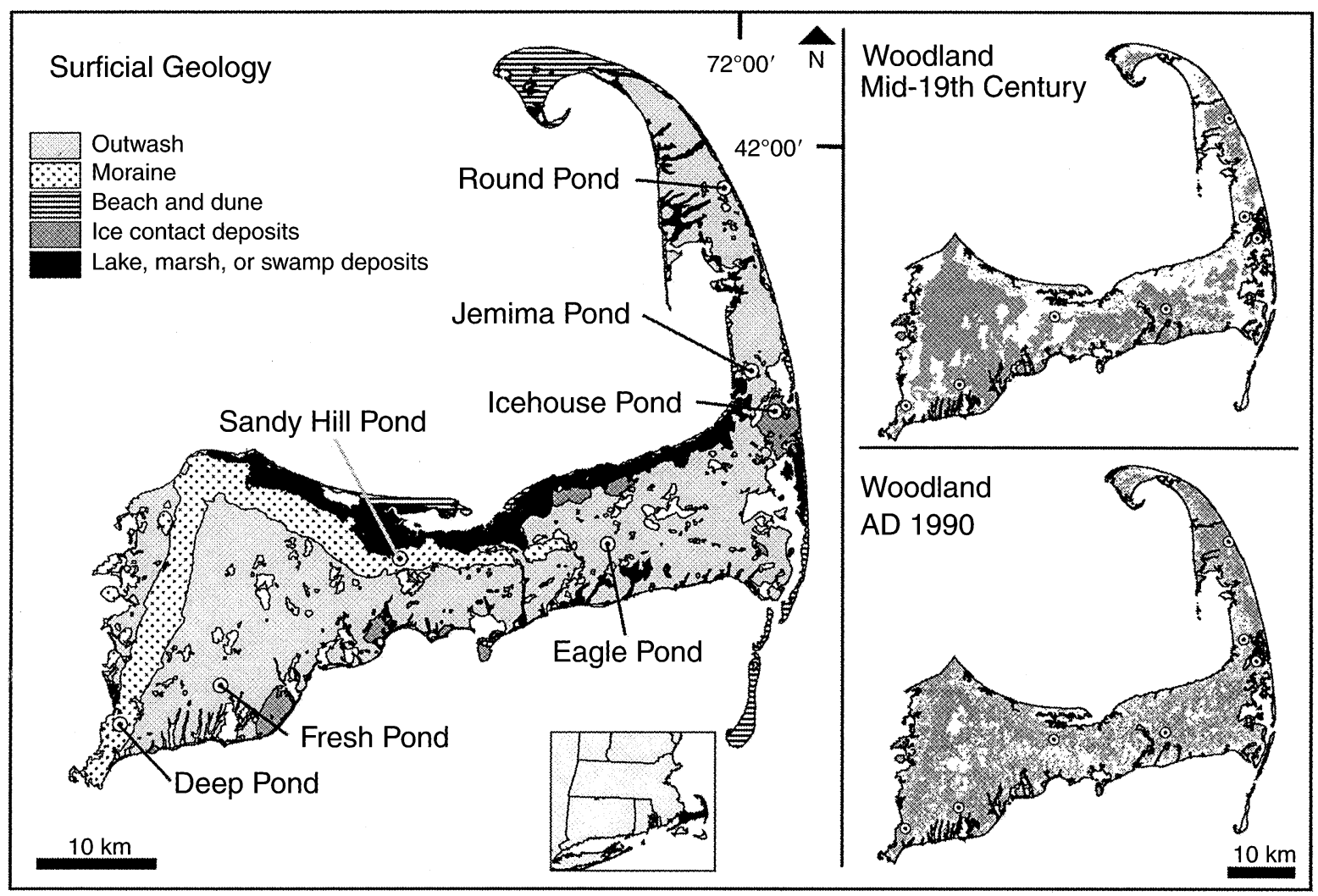

FIG. 1. Location of study sites on Cape Cod, Massachusetts (see inset), in relation to surficial geology (Oldale and Barlow 1986), 19th century woodland (Massachusetts Archives 1830 U.S. Coast and Geodetic Survey 1945-1961), and modern woodland (MassGIS 1991). Round, Eagle, Fresh, and Deep Ponds were dominated by Pinus pollen before European settlement, and the other sites were dominated by Quercus (Fig. 3). In the mid-19th century, at the height of agricultural activity, the coastal areas of Cape Cod had the largest settlements and were clear of forest. The region was $\sim 40 \%$ forested in extensive, cutover stands. Today, $\sim 40 \%$ of the landscape is composed of maturing forests, largely originating at the end of the 19th century.

(Bromley 1935, Ogden 1961, Russell 1983), ranging from dry, barren woodlands to extensive forests of mesic trees such as Fagus and Carya. Some accounts describe open landscapes or forests with little undergrowth that are linked to intentional burning or clearing by Native Americans (Day 1953, Pyne 1982, Vickery and Dunwiddie 1997).

To address these issues, we use paleoecological methods to reconstruct the past 2000 years of change in vegetation and fire on Cape Cod. By doing so, we ask two basic questions. First, what was the presettlement pattern of vegetation and fire on the landscape? Were forests similar and fires ubiquitous throughout Cape Cod or was there variation on a finer spatial scale? Second, how has the pattern of vegetation and fire changed since European settlement? We examine fossil pollen and charcoal preserved in lake sediments (Fig. 1) to compile seven site-based vegetation and fire histories. This study complements ongoing historical and modern research investigating factors influencing modern vegetation composition and distribution (e.g., Eberhardt 2001, Motzkin et al. 2002, Parshall and Foster 2002). Because of its high number of rare habitats and species, coastal New England has one of the highest priorities for protection and conservation in the northeastern United States (Barbour et al. 1998). Development of conservation policy and vegetation management through the use of prescribed fire and other techniques requires a more thorough understanding of spatial and temporal variation in disturbance processes, vegetation composition, and human history (Christensen et al. 1996, Motzkin et al. 1999, Swetnam et al. 1999).

\section{Study AREA}

Pitch pine-oak forests are common along the coast in the glaciated region of northeastern United States from Cape Cod, Massachusetts, to Long Island, New York, and are locally important on xeric, well-drained sites inland (Bromley 1935, Westveld et al. 1956, Forman 1979, Finton 1998, Motzkin et al. 1999). The dominant trees include Pinus rigida (pitch pine) and Quercus spp. (oaks, especially $Q$. alba, $Q$. coccinea, $Q$. rubra, $Q$. ilicifolia, and $Q$. velutina), but Pinus strobus (white pine), Acer rubrum (red maple), Carya spp. (hickory), and Fagus grandifolia (American beech) 
TABLE 1. Characteristics of study lakes including the predominant soils (Fletcher 1993) and landform (Oldale and Barlow 1986).

\begin{tabular}{|c|c|c|c|c|}
\hline Site & $\begin{array}{c}\text { Area } \\
\text { (ha) }\end{array}$ & $\begin{array}{l}\text { Elevation } \\
\quad(\mathrm{m})\end{array}$ & Soil texture & Landform \\
\hline Deep Pond & 1.0 & 23 & $\begin{array}{l}\text { variable: sandy loams to } \\
\text { coarse/loamy sands }\end{array}$ & moraine \\
\hline Sandy Hill Pond & 2.4 & 16 & $\begin{array}{l}\text { variable: sandy loams to } \\
\text { coarse/loamy sands }\end{array}$ & moraine \\
\hline Jemima Pond & 2.2 & 3 & predominantly coarse sands & outwash \\
\hline Icehouse Pond & 1.8 & 19 & $\begin{array}{l}\text { variable: silty/sandy loams to } \\
\text { coarse/loamy sands }\end{array}$ & ice contact \\
\hline Fresh Pond & 5.3 & 7 & predominantly coarse sands & outwash \\
\hline Eagle Pond & 4.0 & 11 & predominantly coarse sands & outwash \\
\hline Round Pond & 1.6 & 4 & predominantly coarse sands & outwash \\
\hline
\end{tabular}

may be abundant locally. Common to many stands is a dense ericaceous shrub understory comprised primarily of Gaylussacia baccata (huckleberry) and Vaccinium spp. (blueberries).

The dominant landforms on Cape Cod are glacially derived (Fig. 1; Oldale and Barlow 1986, Uchupi et al. 1996). The highest elevations $(60 \mathrm{~m})$ are on the topographically variable Buzzards Bay and Sandwich moraines, which occur along northwestern and northern Cape Cod. Much of the rest of the study area is

TABLE 2. Radiocarbon dates and calibrated dates (calculated from CALIB 4.2 [Stuiver and Reimer 1993, Stuiver et al. 1998]) used to create age-depth models for each site (Fig. 2).

\begin{tabular}{|c|c|c|c|c|}
\hline $\begin{array}{c}\text { Site } \\
\text { (year cored) }\end{array}$ & $\begin{array}{c}\text { Depth } \\
(\mathrm{cm})\end{array}$ & $\begin{array}{l}{ }^{14} \mathrm{C} \text { age } \\
(\mathrm{yr} \mathrm{BP})\end{array}$ & $\begin{array}{c}\text { Calibrated } \\
\text { age } \\
\text { (yr ago) }\end{array}$ & $\begin{array}{l}\text { Calibrated } \\
\text { age range, } \\
2 \sigma(\mathrm{yr} \text { ago })\end{array}$ \\
\hline $\begin{array}{l}\text { Deep Pond } \\
\text { (1999) }\end{array}$ & $\begin{array}{l}110 \\
130 \\
169 \\
235\end{array}$ & $\begin{array}{r}705 \pm 40 \\
1090 \pm 40 \\
1782 \pm 40 \\
2305 \pm 50\end{array}$ & $\begin{array}{r}711 \\
1020 \\
1757 \\
2389\end{array}$ & $\begin{array}{c}608-756 \\
977-1115 \\
1651-1868 \\
2223-2411\end{array}$ \\
\hline $\begin{array}{l}\text { Fresh Pond } \\
\text { (1999) }\end{array}$ & $\begin{array}{r}49 \\
79 \\
113 \\
159 \\
199\end{array}$ & $\begin{array}{r}457 \pm 60 \\
760 \pm 40 \\
1126 \pm 40 \\
1673 \pm 50 \\
2142 \pm 50\end{array}$ & $\begin{array}{r}560 \\
723 \\
1055 \\
1605 \\
2192\end{array}$ & $\begin{array}{c}366-607 \\
702-789 \\
1002-1147 \\
1558-1754 \\
2044-2356\end{array}$ \\
\hline $\begin{array}{l}\text { Sandy Hill } \\
\text { (1999) }\end{array}$ & $\begin{array}{r}63 \\
71 \\
85 \\
101 \\
147\end{array}$ & $\begin{array}{r}633 \pm 40 \\
862 \pm 40 \\
932 \pm 40 \\
1138 \pm 40 \\
2014 \pm 60\end{array}$ & $\begin{array}{r}631 \\
798 \\
880 \\
1075 \\
2017\end{array}$ & $\begin{array}{c}599-707 \\
738-959 \\
808-978 \\
1013-1193 \\
1910-2169\end{array}$ \\
\hline $\begin{array}{l}\text { Eagle Pond } \\
\text { (2000) }\end{array}$ & $\begin{array}{r}39 \\
55 \\
81 \\
121 \\
199\end{array}$ & $\begin{array}{r}827 \pm 40 \\
1164 \pm 40 \\
1579 \pm 60 \\
3184 \pm 60 \\
4947 \pm 70\end{array}$ & $\begin{array}{r}781 \\
1111 \\
1542 \\
3436 \\
5706\end{array}$ & $\begin{array}{c}720-842 \\
1024-1222 \\
1396-1619 \\
3365-3617 \\
5636-5941\end{array}$ \\
\hline $\begin{array}{l}\text { Jemina Pond } \\
\text { (1999) }\end{array}$ & $\begin{array}{r}77 \\
91 \\
111 \\
125 \\
139\end{array}$ & $\begin{array}{r}612 \pm 40 \\
926 \pm 60 \\
1458 \pm 40 \\
1735 \pm 40 \\
1962 \pm 40\end{array}$ & $\begin{array}{r}648 \\
878 \\
1394 \\
1706 \\
1960\end{array}$ & $\begin{array}{c}595-701 \\
773-998 \\
1344-1457 \\
1581-1785 \\
1875-2038\end{array}$ \\
\hline $\begin{array}{l}\text { Icehouse Pond } \\
\text { (1999) }\end{array}$ & $\begin{array}{l}179 \\
219 \\
271\end{array}$ & $\begin{array}{r}541 \pm 40 \\
1309 \pm 30 \\
2190 \pm 50\end{array}$ & $\begin{array}{r}590 \\
1312 \\
2225\end{array}$ & $\begin{array}{c}560-691 \\
1223-1341 \\
2093-2384\end{array}$ \\
\hline $\begin{array}{l}\text { Round Pond } \\
\text { (2000) }\end{array}$ & $\begin{array}{r}27 \\
61 \\
105 \\
145\end{array}$ & $\begin{array}{r}617 \pm 40 \\
1468 \pm 40 \\
1872 \pm 40 \\
3171 \pm 40\end{array}$ & $\begin{array}{r}648 \\
1397 \\
1871 \\
3431\end{array}$ & $\begin{array}{c}598-703 \\
1339-1470 \\
1761-1965 \\
3377-3520\end{array}$ \\
\hline
\end{tabular}

outwash, mostly flat, and $<30 \mathrm{~m}$ above sea level. Soil composition is largely controlled by these landforms. Outwash deposits are excessively drained, coarse sands, whereas moraines and ice-contact deposits are a complex of many soil types from coarse sands to sandy loams and silt loams (Fletcher 1993).

Archaeological evidence indicates that Native Americans occupied Cape Cod throughout the Holocene and into the period of European settlement (McManamon 1984, Mahlstedt 1987, Grumet 1995, Dunford and O'Brian 1997). Recent studies demonstrate modest cultural changes in the last 1000 years associated with the arrival of maize but suggest that the populations were seasonally mobile, heavily reliant on marine resources, and not associated with large permanent settlements, horticulture, or forest clearing (Mahlstedt 1987, Little and Schoeninger 1995, Bragdon 1996, Chilton 1999). Burning by Native Americans undoubtedly occurred, but its extent and impact on vegetation are still debated (Russell 1983, Patterson and Sassaman 1988, Bonnicksen 2000).

The first permanent European settlements on Cape Cod were established in the 1630 s, but these were initially small and many areas of the Cape were not occupied until at least 1700. Cattle and sheep grazing were common along the coasts until the early $1800 \mathrm{~s}$ (Kittredge 1968, Stott 1987), but the landscape was still $\sim 40 \%$ forested in the mid-19th century, varying substantially among towns (Fig. 1). Historical sources cite increased fire ignitions from railroads beginning in the mid-19th century, and reports of fires were common in the early part of the 20th century (Dunwiddie and Adams 1995, Eberhardt 2001).

\section{Methods}

We selected seven lakes to include both broad geographic coverage and edaphic variability on Cape Cod (Fig. 1, Table 1). Based on surficial geology, we selected two lakes on morainal deposits (Deep and Sandy Hill), three lakes on outwash deposits (Fresh, Eagle, Jemima, and Round), and one on ice-contact deposits (Icehouse). All lakes are small, ranging in size from 1 to 5.3 ha and should collect a significant proportion of pollen from vegetation within several kilometers (Pren- 


\section{Oak Group}

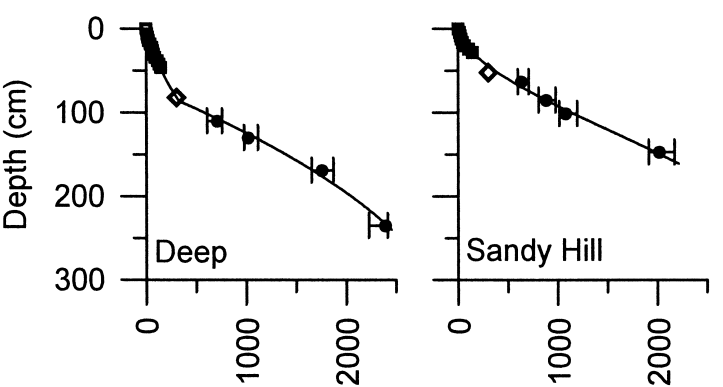

Pine Group

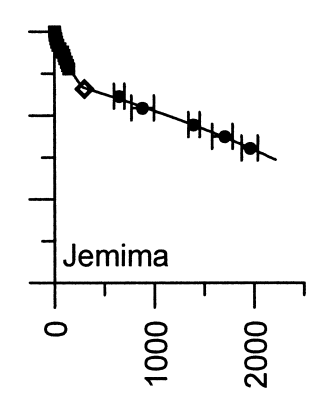

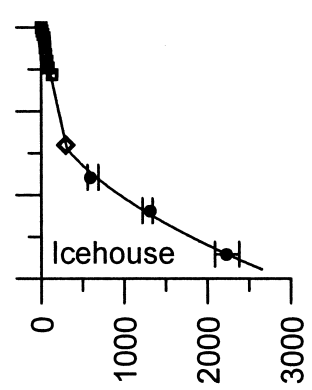

Age (yr ago)

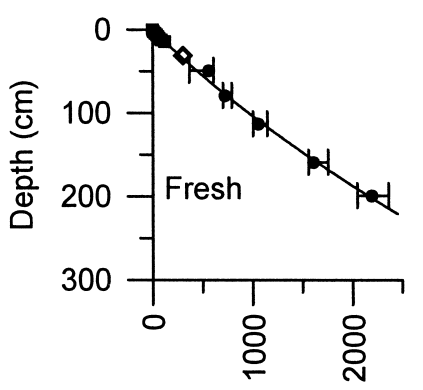

Age (yr ago)

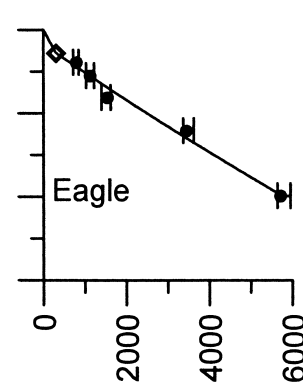

Age (yr ago)
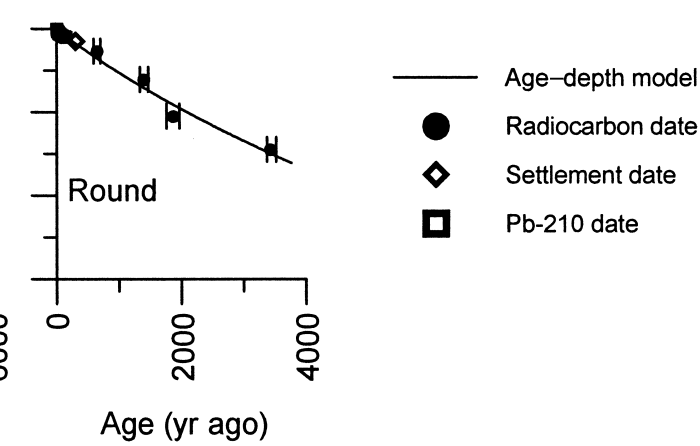

FIG. 2. Age-depth models for each site based on radiocarbon dates, $\mathrm{Pb}-210$ dates, and the beginning of European settlement (300 years ago, AD 1700) identified by changes in pollen. Bars on radiocarbon dates represent the age range of each date derived from the probability method of CALIB 4.2 (Table 2). The height of the bars does not represent sample depth.

tice 1985, Jackson 1990, Sugita 1993, 1994). The uppermost lake sediments and the sediment-water interface were sampled with a $7 \mathrm{~cm}$ diameter polycarbonate tube fitted with a piston, and deeper sediments were retrieved with a $5 \mathrm{~cm}$ diameter Livingstone piston corer. Organic content of sediments was estimated from the percentage dry mass lost on ignition (LOI) at $550^{\circ} \mathrm{C}$ (Bengtsson and Enell 1986).

\section{Pollen}

Sediment samples from $1 \mathrm{~cm}$ depths were selected in equal intervals downcore, and sample preparation for pollen analysis followed standard procedures (Faegri and Iversen 1989), including sieving through a 180$\mu \mathrm{m}$ mesh, adding a known number of marker grains, and identifying pollen at $400 \times$ magnification until 500 tree and shrub pollen grains were identified. Pollen percentages are based on a pollen sum of upland trees, shrubs, and herbs, plus pteridophyte spores. Depending on site, the time period represented by each pollen sample is $\sim 5-20$ years, with gaps between samples on the order of 100-200 years in older sediments and 1020 years in younger sediments.

We identified major changes in vegetation at each site by clustering pollen spectra using the constrained incremental sum of squares method on square-root transformed pollen percentages (Grimm 1987). The analysis included all upland pollen types that comprised $>2 \%$ of the pollen sum for at least one sample in any of the seven sites. The same pollen types were included in all clusterings, and the results were used to determine the onset of European land clearance and other changes in pollen stratigraphy.

We identified similarities in past forest composition among sites using Detrended Correspondence Analysis (DCA) of all fossil pollen spectra combined. The pollen types for this analysis included upland, nonherbaceous taxa from closed forest whose abundance exceeded $2 \%$ of the pollen sum in at least one sample and whose occurrence is not associated with the local habitats surrounding a lake (e.g., Acer rubrum, Nyssa sylvatica, Clethra). Eight types fulfill these criteria: Pinus, Quercus, Tsuga canadensis, Betula, Acer saccharum, Fagus grandifolia, Carya, and Pteridium.

\section{Charcoal}

"Microscopic" charcoal fragments encountered along transects on the same slides used to count pollen were measured at $200 \times$ with an imaging system. Only charcoal pieces $>10 \mu \mathrm{m}$ in length were measured, because small fragments are difficult to distinguish from opaque mineral grains. The number of marker grains present along the transects were also counted. Charcoal abundance of this size fraction is expressed both as 


\section{a) Oak Group sites}
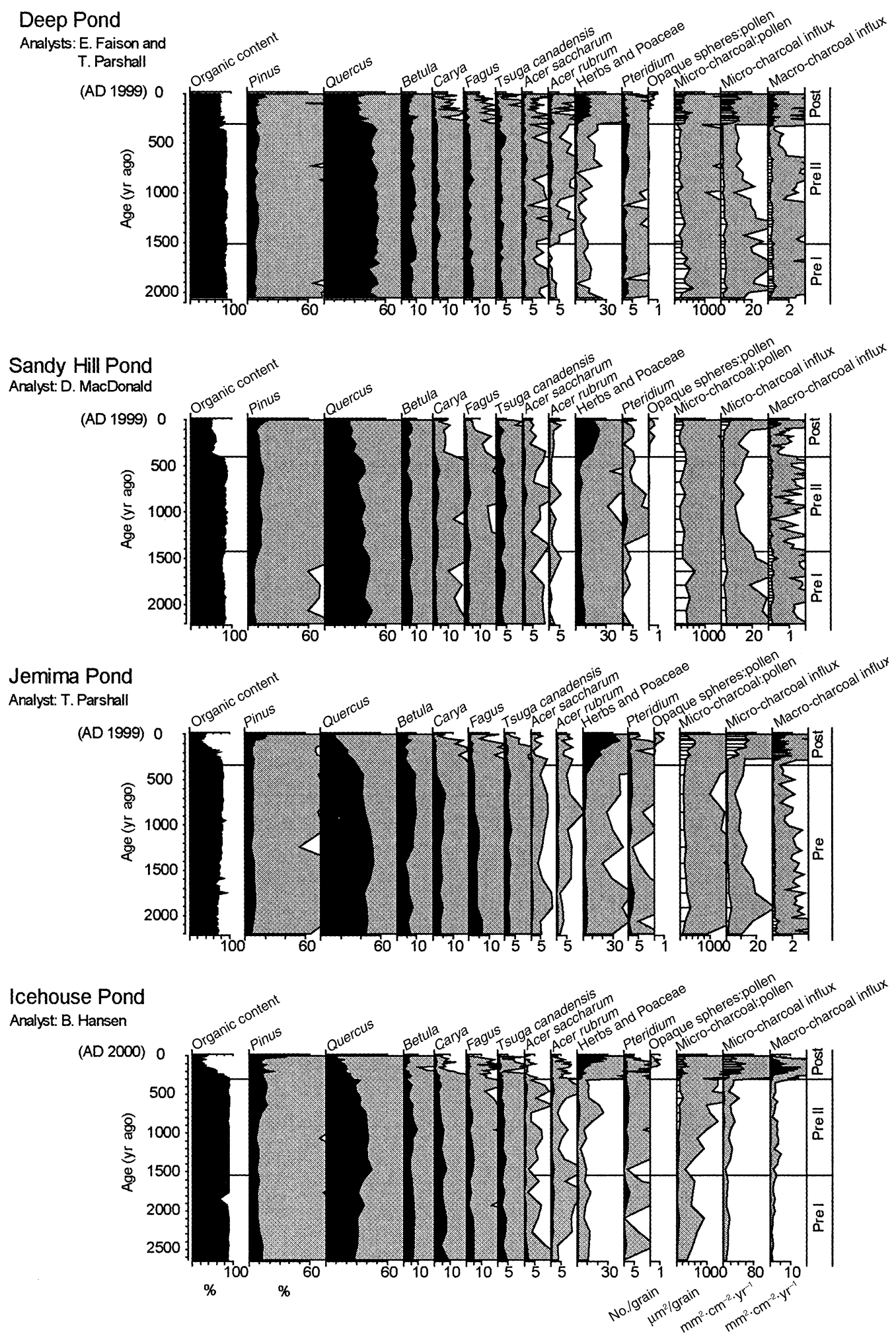


\section{b) Pine Group sites}
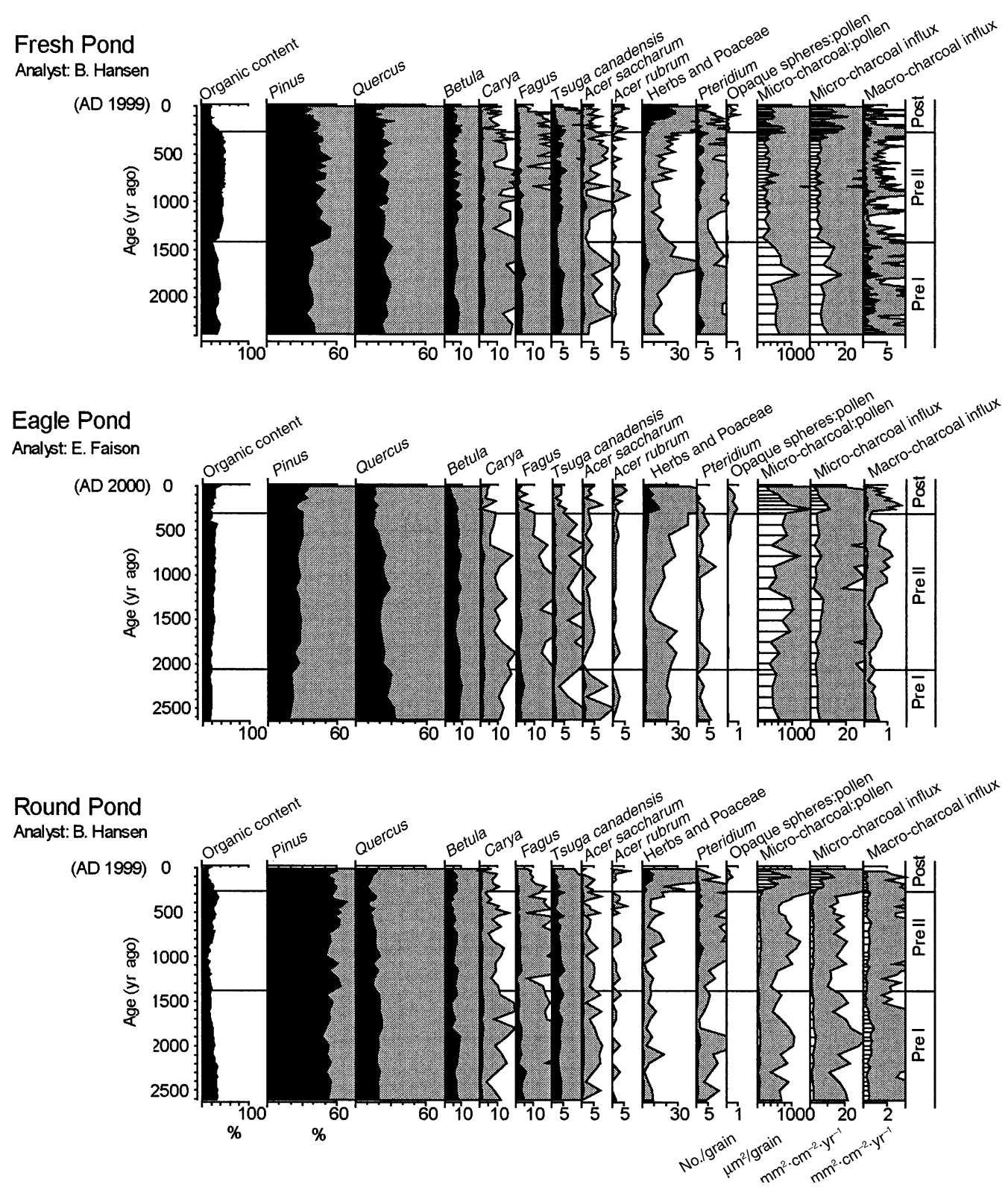

FIG. 3. Results of sediment analyses of sites in (a, facing page) Oak and (b) Pine Groups, which were identified by ordination of pollen spectra (Fig. 4). Organic content is the percentage dry mass lost on ignition at $550^{\circ} \mathrm{C}$. Pollen is given as the percentage of the total pollen sum. Horizontal scales are not uniform among types, and gray shading is a $10 \times$ exaggeration. Opaque spheres values are the number of spheres counted per pollen grain. Charcoal is expressed as either a ratio of charcoal to pollen $\left(\mu \mathrm{m}^{2} / \mathrm{grain}\right)$ or as influx $\left(\mathrm{mm}^{2} \cdot \mathrm{cm}^{-2} \cdot \mathrm{yr}^{-1}\right)$. Horizontal lines are zone boundaries identified by clustering of pollen spectra in each site separately.

influx (in square millimeters per square centimeter per year) and as a ratio of the total charcoal area measured for each slide and the upland pollen sum (square micrometers per pollen grain).

"Macroscopic" charcoal was assessed in sediment samples (1-3 $\mathrm{cm}^{3}$ portions) that were dispersed with $\mathrm{KOH}$ and retained in a $180-\mu \mathrm{m}$ screen. Because this approach does not require pollen preparation, the num- ber of macroscopic charcoal samples analyzed is greater than the number of microscopic samples. However, except for Fresh Pond, samples are noncontiguous, with gaps between samples representing 10-50 years. For a subset of samples at each site, the area of all charcoal fragments was measured with an imaging system at $20 \times$ magnification. For each subset, the correlation between the number of pieces and total area 
a) Presettlement samples

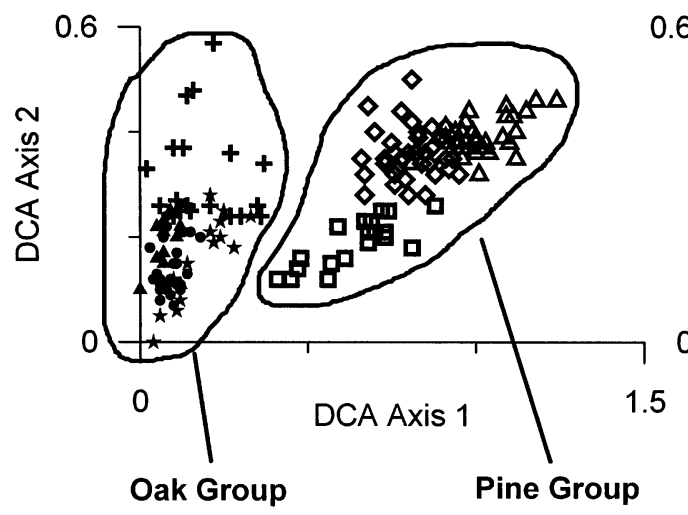

b) Postsettlement samples

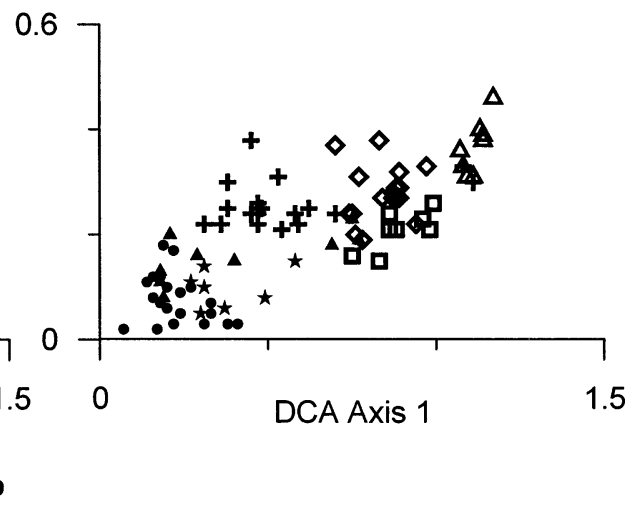

FIG. 4. Ordination of fossil pollen assemblages from all sites. (a) Presettlement samples are shown separately from (b) postsettlement samples to highlight the difference in vegetation between the two periods. The Oak Group includes Icehouse $(+)$, Jemima $(\boldsymbol{\Delta})$, Sandy Hill $(\star)$, and Deep $(\bullet)$ Ponds. The Pine Group includes Round $(\triangle)$, Eagle $(\square)$, and Fresh $(\diamond)$ Ponds.

of fragments is nearly linear, and counts only were made for subsequent samples from the same site. Macroscopic charcoal influx on an area basis (in square millimeters per square centimeter per year) was calculated from these counts using the site-specific relationship between pieces and area.

\section{Chronology}

We calculated sediment age before European settlement (Table 2) from calibrated AMS radiocarbon dates of homogenized sediment, each incorporating $5-10 \mathrm{~cm}^{3}$ spanning $1 \mathrm{~cm}$ of sediment depth. Macrofossils are rare in these sediments and the surrounding landforms do not contain carbonates. We also assessed sediment $\mathrm{Pb}$ 210 activity to provide time control for the past 150 years (Eakins and Morrison 1978, Binford 1990). Opaque spheres, identified during microscopic charcoal analysis, indicate an increase in fossil-fuel combustion since the late 19th century (Clark and Patterson 1984, Rose et al. 1995) and are used to reinforce the chronology.

We created age-depth equations from second- and third-order polynomials including all radiocarbon and $\mathrm{Pb}-210$ dates and the depth representing European "settlement" identified by pollen classification (Fig. 2). Since it is impossible to accurately determine the exact date and extent of landscape clearance around each site, we use AD 1700 (300 years ago) to approximate the date of European settlement for all sites. We acknowledge that some of the earliest European settlements nearby occurred as much as 70 years before that time, but we believe that their size was too small to make an impact on the landscape that would show up in these pollen records. This estimated date compares well to predicted dates based on interpolating among $\mathrm{Pb}-210$ and ${ }^{14} \mathrm{C}$ ages.

For three lakes (Deep, Jemima, and Icehouse), separate age-depth equations for presettlement and postsettlement periods were created because sedimentation rates increase substantially across this time horizon. On the basis of Pb-210 dates, pollen, and organic content, we suspect that the sediments of the past 300 years in Eagle Pond may have been slightly disturbed, so we constructed a radiocarbon-based model for the presettlement period and linearly interpolated between the settlement horizon (300 years ago) and the top of the core. Although there are instances where the age model and radiocarbon dates do not agree exactly (e.g., Round Pond), in most cases the fit is very good. Since our goal is to compare charcoal influx, we feel that it is better to construct age models consistently among sites than to interpolate between dates.

\section{RESULTS}

\section{Sediment stratigraphy and pollen changes}

European settlement is clearly identified by an increase in herbs and Poaceae, which represent forest clearance and the initiation of open landscapes (Fig. 3 ). At the same time, the rate of sediment accumulation rises at many sites (Fig. 2) and organic content drops (Fig. 3). Pinus pollen also increases in the late-settlement period at three of four sites in the Oak Group (Fig. 3a, see Results: Comparison of pollen among sites).

Except for Jemima Pond, we have divided the presettlement pollen stratigraphy into two zones based on cluster analyses (Fig. 4). The date of transition between these zones is surprisingly consistent among sites, around 1400-1500 years ago, and we have named the presettlement zones consistently (as Pre I and Pre II) for ease of discussion and to summarize charcoal results (Fig. 5). Eagle Pond is the only site where the date of this boundary differs, but even here the actual radiocarbon date at the boundary depth is $1500 \mathrm{yr} \mathrm{BP}$ (Table 2: Eagle Pond, $81 \mathrm{~cm}$ ). Between the two presettlement zones, Pinus becomes more abundant at Fresh, Sandy Hill, Eagle, and Round Ponds and Quercus becomes more abundant at Icehouse Pond. 

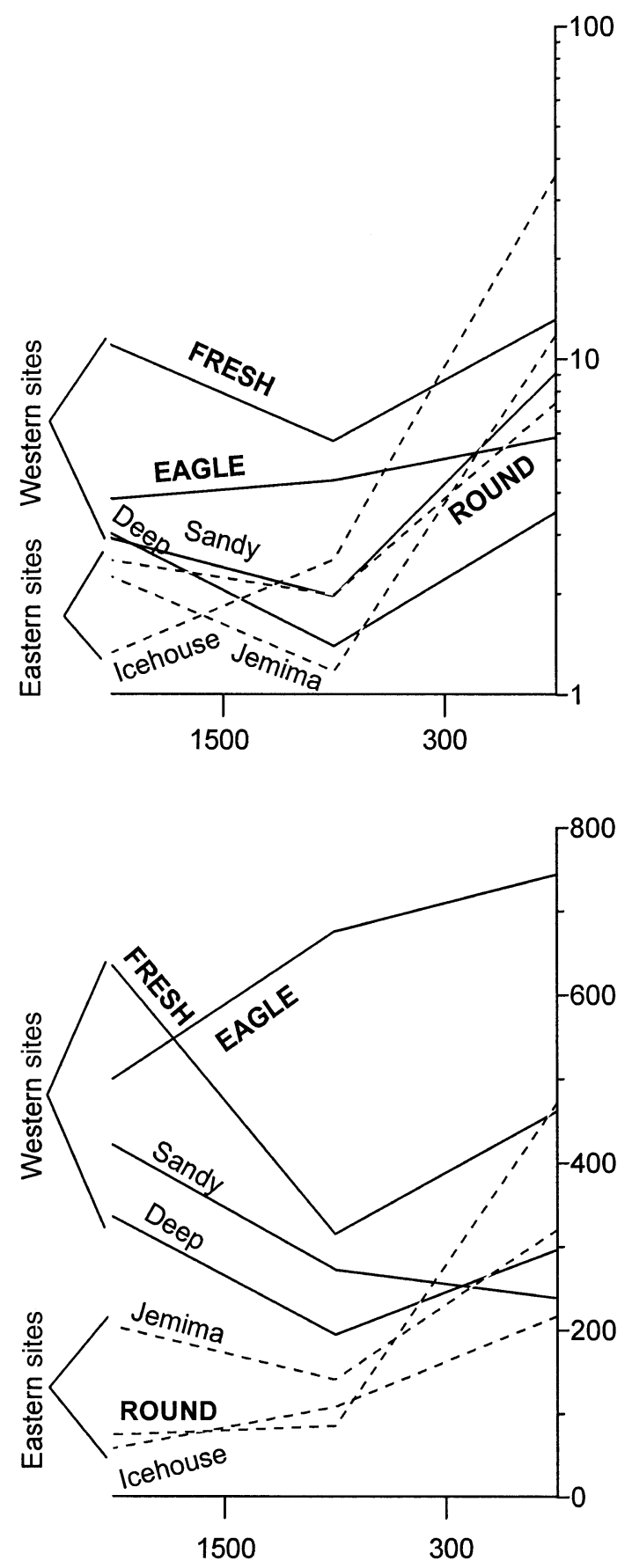

Age (yr ago)

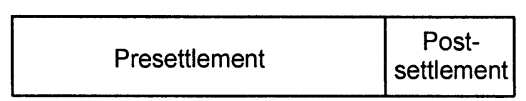

FIG. 5. Average charcoal abundance for three time periods: Presettlement I ( $\sim 1500-2500$ years ago), Presettlement II ( 300-1500 years ago), and Postsettlement $(0-300$ years ago). Charcoal influx (note the log scale) is a sum of both microscopic and macroscopic size fractions. Time periods were identified by pollen classification as shown in Fig. 3, but the precise age ranges vary slightly among sites. For Jemima Pond, where no presettlement pollen zones were

\section{Comparison of pollen among sites}

When only presettlement pollen assemblages are considered, the seven sites comprise two main groups (Fig. 4a). Quercus, Fagus, and Carya are more abundant in Oak Group sites (Icehouse, Jemima, Sandy Hill, and Deep Ponds), whereas Pinus pollen dominates the sediments of Pine Group sites (Eagle, Fresh, and Round Ponds). For a subset of samples at each Pine Group site, we quantified the proportion of Pinus rigida type and found that it is overwhelmingly the most abundant Pinus pollen type. The presettlement organic content of sediments is much higher in lakes of the Oak Group $(>75 \%)$ than the Pine Group $(<60 \%)$. Following European settlement, sites in the Oak Group also show a greater decline in organic content (Fig. 3) and a more substantial rise in sedimentation rates (Fig. 2).

The seven sites are less clearly separable into groups when pollen from only the postsettlement period is considered (Fig. 4b). A gradient from Quercus- to Pinusdominated stands persists in postsettlement pollen, but the overlap among sites is higher than before European settlement because Oak Group sites have become more similar to Pine Group sites. In Oak Group sites, Quercus declines substantially, along with Fagus, Carya, and Tsuga, whereas Pinus increases, especially in the late settlement period.

\section{Charcoal}

The influx of smaller, microscopic charcoal fragments is 5-10 times greater than the influx of larger, macroscopic charcoal (Fig. 3). In most of the diagrams in Fig. 3, each sample averages charcoal influx for 520 years, with gaps between samples on the order of 50-100 years. Therefore, we restrict our assessment of changes in fire to the three broad time periods apparent in the pollen stratigraphy (Fig. 5). Variability in charcoal influx through time is, in most cases, similar between macroscopic and microscopic size fractions, and we combined them to estimate total charcoal influx.

Presettlement charcoal abundance varies with both landform and geography. Charcoal abundance is consistently highest at Fresh and Eagle Ponds, which are on outwash in western Cape Cod and members of the Pine Group (Fig. 5). Charcoal abundance is next highest in samples from Deep and Sandy Hill Ponds, sites on moraines in western Cape Cod and members of the Oak Group. The lowest values are from the three sites on eastern Cape Cod: Icehouse, Jemima, and Round Ponds. During the presettlement period, charcoal declines substantially around 1500 years ago in Fresh, Deep, and Sandy Hill Ponds and modestly at Round Pond between 1700 and 1200 years ago. Over this same

identified, we used a cutoff of 1500 years ago. Sites from the Pine Group (see Fig. 4) are in bold letters. 
interval, charcoal influx increases at Eagle and Icehouse Ponds.

Overall, charcoal abundance increases sharply following European settlement. Only at Sandy Hill Pond do charcoal values decline, and here only when charcoal:pollen ratio values are considered. Neither the magnitude of these changes across the settlement period nor the absolute charcoal abundances following settlement are clearly related to geographical location, landform, or pollen group as identified above.

\section{DisCUSSION}

A paleoecological study of this system is valuable because it elucidates the extent and direction of ecological change before and during a time when the intensity and type of human activity shifted substantially. By selecting many sites within a small geographic area we can address two major questions of landscape change over the past 2000 years. First, how variable was vegetation composition and fire across the landscape before extensive settlement, and what factors are associated with this spatial pattern? Second, to what extent and in what direction did vegetation and fire change over the period of European settlement, and what were the major causes of these changes?

\section{Vegetation reconstruction and resolution of pollen data}

We have shown that two lakes as close as $10 \mathrm{~km}$ can differ sharply in their pollen stratigraphy over the past 2000 years. For example, Deep and Fresh Ponds are $10 \mathrm{~km}$ apart and are less similar to each other than they are to sites in other parts of Cape Cod. In similar fashion, although Round Pond is only $15 \mathrm{~km}$ from Jemima Pond, its presettlement pollen values for Pinus are more than five times higher. These results support other empirical studies in New England finding that regional pollen from plants growing inland does not impede an interpretation of local vegetation from pollen in lakes along the coast (Winkler 1985, Dunwiddie 1990, Jackson and Dunwiddie 1992). That presettlement pollen assemblages show distinct separation of sites into groups is especially notable, because Pinus and Quercus pollen disperses relatively long distances and might be expected to overwhelm the pollen spectra (Prentice 1985, Jackson and Lyford 1999).

Clearly, Cape Cod was largely forested at the time when Europeans first arrived in New England. Based on the low abundance of herb and grass pollen at all sites, there is little evidence for extensive grasslands or heathland vegetation before European arrival (Foster and Motzkin 1999, Dunwiddie 2001). The forests were comprised primarily of Pinus rigida and Quercus spp., but their abundance was variable across the landscape and some areas had a much larger component of Fagus and Carya than today. A much greater degree of heterogeneity in forest composition probably existed locally that is not represented in these pollen records. For example, Atlantic white cedar swamps and other lowland vegetation types were certainly present (Motzkin et al. 1993), but our selection of lakes does not allow us to consider them. As mentioned above, since the vegetation is dominated by pollen from highly dispersed types, fine details of past vegetation composition are not detectable from our data. Furthermore, important structural differences in oak forests cannot be addressed because differences in oak pollen types cannot be easily identified.

\section{Presettlement distribution of vegetation and fire}

We find that much of the variability in presettlement forest composition is closely tied to landform and soil characteristics. Sites dominated by Pinus rigida (Pine Group) are surrounded by deep, well-drained, outwash deposits, while sites dominated by Quercus and other hardwoods (Oak Group) occur either on moraines (Deep and Sandy Hill) or ice-contact deposits (Icehouse), which have greater topographic variability and soil composition ranging from coarse sands to sandy loams and silt loams (Table 1). Jemima Pond is an exception in the Oak Group, because the surrounding soils are predominantly outwash sands. Perhaps hardwoods have an advantage over Pinus here as a result of higher water availability, since the surrounding landscape is relatively low in elevation and several lakes surround the site. The predominance of hardwoods could also be a response to lower fire occurrence.

The strong link between landform and presettlement forest composition is supported by other paleoecological studies from Cape Cod (Winkler 1985, Tzedakis 1992; W. A. Patterson, unpublished data), nearby Plymouth County (Backman 1984, Patterson and Backman 1988) and Martha's Vineyard (Foster et al. 2002). Proprietor records further corroborate the pattern, with oak trees cited more often on moraines and pines mostly cited on outwash (Hall et al. 2002, Motzkin et al. 2002). Mid-19th century historical observations and maps also indicate that the woodlands of eastern Cape Cod were dominated by Quercus near Jemima and Icehouse Ponds and by Pinus in the vicinity of Round and Eagle Ponds (U.S. Coast and Geodetic Survey 18451861, Dwight 1969, Thoreau 1988).

Our results indicate that presettlement fire is closely tied to landform and vegetation, especially on western Cape Cod. Charcoal is most abundant in the two Pine Group sites (Fresh and Eagle) occurring on outwash deposits and is lower in the two Oak Group sites (Deep and Sandy Hill) located on morainal deposits (Table 1, Fig. 5). This pattern is consistent with the ecology of these forest communities. Pinus rigida is a shade-intolerant species that does not regenerate well in thick leaf litter (Little and Garrett 1990), and successful stand establishment occurs primarily after moderate to severe fires or other physical disturbances that remove resident trees and organic litter. $P$. rigida occurs today almost exclusively on sandy, well-drained soils (Little 1979, Olsvig et al. 1979, Little and Garrett 1990, Motzkin et al. 1999). In the absence of severe or frequent 
fire, Quercus often replaces $P$. rigida with other hardwoods such as Fagus and Carya, becoming a larger component of the forests on more mesic sites (Little 1979, Patterson et al. 1984, Chokkalingham 1995).

The abundance of charcoal in many of these lakes is among the highest in all of New England, indicating that the occurrence of fire was, indeed, much higher in pitch pine-oak forests along the coast than in other vegetation types (Patterson and Backman 1988, Parshall and Foster 2002). Charcoal influx values from Fresh and Eagle Ponds are similar to other pitch pine forests in New England and are comparable to pine forests of the Great Lakes region, though not as high as the Midwestern prairies where fires probably burned annually (Clark 1990, Clark and Royall 1996). The lowest influx values on eastern Cape Cod (Icehouse, Jemima, and Round) are similar to those from oakdominated forests inland (Parshall and Foster 2002).

The low occurrence of fire on eastern Cape Cod is contrary to expectations for several reasons. For one, since Pinus rigida dominated the forests for $>2000$ years around Round Pond, fires are expected to have been common. One possible explanation for this discrepancy is that the abundance of fossil charcoal is underestimating the true occurrence of past fires. A large portion of the potential regional source area is ocean, not land, and only local fires would contribute charcoal to the basin. The smaller ratio of charcoal to pollen at Round Pond compared to other Pine Group sites supports this explanation, since the potential source area for pollen should also be reduced. An alternative explanation is that the actual occurrence of fire may have been lower. This is a real possibility since the chance of ignitions on the narrow landmass of eastern Cape Cod is lower than elsewhere and several barriers to the spread of fire exist. If this is true, Pinus rigida persisted at this site despite its perceived requirement for fire. Unfortunately, we do not have enough information at this time to determine the relative importance of these two factors-reduced source area and lower occurrence of fire-on reducing charcoal influx at Round Pond.

Archaeological evidence and early historical accounts place Native American populations and settlements in eastern Cape Cod, especially near Jemima and Icehouse Ponds (McManamon 1984, Mahlstedt 1987, Grumet 1995). If Native Americans were intentionally setting fires, their effects are not clearly seen in our results. This could mean that the fires did not produce large amounts of charcoal (e.g., low-intensity surface fires), and our methods are unable to detect them. Alternatively, fires may actually have been less common than has been asserted (Pyne 1982, Patterson and Sassaman 1988, Whitney 1994, Bonnicksen 2000), and Native Americans did not substantially affect widespread fire occurrence. Although human populations in New England were probably highest along the coast, there is little evidence that settlements were large or persisted for as long as Native American populations elsewhere in eastern North America (Clark and Royall 1995, 1996, Bragdon 1996, Chilton 1999). Perhaps Native American impacts increased the abundance of fires only locally, which might not be observed in these particular lakes since fires must occur near a basin to be detected (Sugita et al. 1997).

\section{Changes in vegetation and fire 1500 years ago}

The change in presettlement pollen and charcoal at all but one of the lakes around 1500 years ago indicates a surprisingly synchronous shift in forest composition and fire. Although the nature and extent of these changes are not the same at all sites, several consistent patterns are evident. Charcoal abundance declines at the three westernmost sites (Deep, Fresh, and Sandy Hill) and is associated with a shift toward higher Pinus pollen at two of them (Fresh and Sandy Hill). An increase in Pinus pollen occurs at other locations along the coast of New England between 1500 and 2000 years ago (Butler 1959, Winkler 1985, Foster et al. 2002), although comparable charcoal records are lacking. In contrast, fire apparently became more important at this time around Eagle Pond, where Pinus rose and Quercus declined, and Icehouse Pond, where Quercus increased.

Regional changes in climate or human activity are the two most likely explanations for the coincidence of these changes. The number of archaeological sites identified suggests that the size of the human population on Cape Cod may have peaked around 1300 years ago (Mahlstedt 1987). However, an increase in fire by Native Americans would presumably increase the occurrence of fire. As with the unexpectedly low occurrence of fire in eastern Cape Cod, we do not find evidence to support a widespread effect of Native Americans.

A more likely explanation is that fire declined as climate became effectively wetter (Webb et al. 1993, Almquist et al. 2001, Shuman 2001). Although one other study also shows evidence for declining charcoal abundance over the past 3000-5000 years on eastern Cape Cod (Winkler 1985, 1997), other Holocene-scale records are lacking to say whether this was a general pattern in New England. Our current understanding of the relationship between fire and past climate change is not well developed. For example, fires have apparently increased in eastern Canada over the Late Holocene as climate became wetter, perhaps because of a change in the seasonal distribution of precipitation (Carcaillet and Richard 2000). Our conclusion is that fire on Cape Cod has declined in importance over the past 2000 years in step with cooler, moister climate rather than in response to human activities, but this pattern requires further consideration.

\section{Impact of European settlement}

Clearly, the greatest amount of change over the past 2000 years took place with the arrival of permanent European settlements in the mid to late 1600s. Many 
of the forests of Cape Cod were either cleared by the late 1700 s or altered extensively by selective cutting (Altpeter 1937, Dwight 1969). This transformation from a wooded to open and highly disturbed landscape appears as an increase in the abundance of herb and grass pollen and a reduction in hardwood trees, especially Quercus, Fagus, and Carya. The openness of the modern landscape that was initiated at this time continues to the present, although the arrangement of wooded and open lands obviously changed over the past 150 years (Fig. 1). Sites that show the earliest and most extensive changes were dominated by hardwoods before settlement (Oak Group) and had a much larger reduction in organic matter and increasing sedimentation rate than sites previously dominated by Pinus rigida, presumably a result of greater erosion of the uplands. These sites may have been more desirable for grazing and agriculture because of their finer-textured and more mesic soils or for their source of hardwood trees for wood products. Forests around each of the lakes in the Oak Group were cleared either completely (Jemima and Icehouse) or substantially (Sandy Hill and Deep) in the mid-1800s (Fig. 1).

The rise in charcoal at almost every site suggests that fire was a more common part of the postsettlement landscape than for at least the previous 1000 years, a pattern that is evident in other regional fire histories (Patterson and Backman 1988, Russell et al. 1993, Clark and Royall 1996, Maenza-Gmelch 1997). European land use practices are likely to have increased fire occurrence as a result of intentional burning, an accumulation of woody fuels following land clearance, and higher frequency of accidental ignitions from the larger population size (Deyo 1890, Altpeter 1937, Pyne 1982, Patterson et al. 1984, Williams 1989, Dunwiddie and Adams 1995). Written accounts of fires prior to the middle of the 19th century are scarce, but several town ordinances were in place in the early settlement period that restricted their use to particular seasons (Hough 1882), so Europeans were obviously burning the land at the time of initial clearance.

Two caveats require some notice. First, higher levels of postsettlement charcoal could be partly an artifact of redeposition from upland soils, though we do not believe that this was significant. Charcoal:pollen ratio values, which take into account redeposited charcoal by including pollen redeposited at the same time, also increase after settlement. In addition, although the amount of unidentifiable pollen rises at settlement, it does not comprise a large portion of total pollen, suggesting that the influx of both older pollen and charcoal from upland soil was probably not large. Second, the resolution of our charcoal data does not reveal a reduction in fires over the past 50 years as a result of effective fire suppression. Therefore, the modern structure and composition of forests are likely a result of the absence of recent fire that we cannot detect in our records, in addition to regeneration following land clearance and higher fire in the early settlement period that we can detect.
The main forces that have influenced ecosystem processes on the postsettlement landscape of Cape Cod were forest clearance and an increase in fire. Although pollen assemblages show a gradient in forest composition today from dominance by hardwoods to dominance by Pinus, the edaphically controlled landscape mosaic of the presettlement forests is not nearly as distinct. Apparently, Cape Cod forests today are more similar to each other than before the arrival of Europeans, in part because the open agricultural landscapes of 150 years ago have become reforested with less Quercus, Fagus, and Carya and more Pinus. These results corroborate a trend across New England toward less variation in vegetation composition on the modern landscape than in the past (Russell et al. 1993, Foster et al. 1998b, Fuller et al. 1998).

\section{ACKNOWLEDGMENTS}

We thank S. Clayden, E. J. Cushing, R. Eberhardt, J. Harrod, G. Motzkin, S. Jackson, and B. Shuman for comments and discussion on the project and review of the manuscript, B. Hall for assistance with historical data and map generation, and E. Doughty, J. Murnock, M. Kirwan, and S. Barry for field and laboratory assistance. This study was supported by grants from the National Science Foundation (DEB 0008056), the A. W. Mellon Foundation, and The Nature Conservancy Ecological Research Program.

\section{Literature Cited}

Almquist, H., A. C. Dieffenbacher-Krall, R. Flanagan-Brown, and D. Sanger. 2001. The Holocene record of lake levels of Mansell Pond, central Maine, USA. Holocene 11(2): 189-201.

Altpeter, L. S. 1937. A history of the forests of Cape Cod. Thesis. Harvard Forest, Harvard University, Petersham, Massachusetts, USA.

Backman, A. E. 1984. 1000-year record of fire-vegetation interactions in the northeastern United States: a comparison between coastal and inland regions. Thesis. University of Massachusetts, Amherst, Massachusetts, USA.

Barbour, H., T. Simmons, P. Swain, and H. Woolsey. 1998. Our irreplaceable heritage. Natural Heritage and Endangered Species Program, Westborough, Massachusetts, USA.

Bengtsson, L., and M. Enell. 1986. Chemical analysis. Pages 423-454 in B. E. Berglund, editor. Handbook of Holocene palaeoecology and palaeohydrology. John Wiley and Sons, Chichester, UK.

Binford, M. W. 1990. Calculation and uncertainty analysis of Pb210 dates for PIRLA project cores. Journal of Paleolimnology 3:253-267.

Bonnicksen, T. M. 2000. America's ancient forests: from the ice age to the age of discovery. John Wiley and Sons, New York, New York, USA.

Bragdon, K. J. 1996. Native people of southern New England 1500-1650. University of Oklahoma Press, Norman, Oklahoma, USA.

Bromley, S. W. 1935. The original forest types of southern New England. Ecology 5:61-89.

Butler, P. 1959. Palynological studies of the Barnstable Marsh, Cape Cod, Massachusetts. Ecology 40:735-737.

Carcaillet, C., and P. J. H. Richard. 2000. Holocene changes in seasonal precipitation highlighted by fire incidence in eastern Canada. Climate Dynamics 16:549-559.

Chilton, E. S. 1999. Mobile farmers of pre-contact southern New England: the archaeological and ethnohistoric evidence. Pages 157-176 in J. P. Hart, editor. Current North- 
east paleoethnobotany. New York State Museum Bulletin Number 494.

Chokkalingam, U. 1995. Spatial and temporal patterns and dynamics in old-growth northern hardwood and mixed forests of northern Maine. Thesis. University of Massachusetts, Amherst, Massachusetts, USA.

Christensen, N. L., et al. 1996. The report of the Ecological Society of America committee on the scientific basis for ecosystem management. Ecological Applications 6:665691.

Clark, J. S. 1990. Fire and climate change during the last 750 years in northwestern Minnesota. Ecological Monographs 60:135-159.

Clark, J. S., and W. A. Patterson. 1984. Pollen, Pb-210, and opaque spherules: an integrated approach to dating and sedimentation in the intertidal environment. Journal of Sedimentary Petrology 54(4):1251-1265.

Clark, J. S., and P. D. Royall. 1995. Transformation of a northern hardwood forest by aboriginal (Iroquois) fire: charcoal evidence from Crawford Lake, Ontario, Canada. Holocene 5(1):1-9.

Clark, J. S., and P. D. Royall. 1996. Local and regional sediment charcoal evidence for fire regimes in presettlement north-eastern North America. Journal of Ecology 84:365382.

Cronin, W. 1983. Changes in the land. Hill and Wang, New York, New York, USA.

Day, G. M. 1953. The Indian as an ecological factor in the northeastern forest. Ecology 34:329-346.

Deyo, S. L., editor. 1890. History of Barnstable County, Massachusetts. Blake, New York, New York, USA.

Dunford, F., and G. O'Brian. 1997. Secrets in the sand: the archaeology of Cape Cod. Parnassus Imprints, Hyannis, Massachusetts, USA.

Dunwiddie, P. W. 1990. Postglacial vegetation history of coastal islands in southeastern New England. National Geographic Research 6(2):178-195.

Dunwiddie, P. W. 2001. Using historical data in ecological restoration: a case study from Nantucket. Pages 367-390 in D. Egan and E. A. Howell, editors. Historical ecology handbook. Island Press, Washington, D.C., USA.

Dunnwiddie, P. W., and M. B. Adams. 1995. Fire suppression and landscape change on Outer Cape Cod 1600-1994. U.S. Department of the Interior, Washington, D.C., USA.

Dwight, T. 1969. Travels in New England and New York. Originally published 1821. Harvard University Press, Cambridge, Massachusetts, USA.

Eakins, J. D., and R. T. Morrison. 1978. A new procedure for the determination of lead-210 in lake and marine sediments. International Journal of Applied Radiation and Isotopes 29:531-536.

Eberhardt, R. W. 2001. Implications of land-use legacies in the sand plain vegetation of Cape Cod National Seashore. Harvard Forest, Harvard University, Cambridge, Massachusetts, USA.

Faegri, K., and J. Iversen. 1989. Textbook of pollen analysis. Fourth edition. John Wiley and Sons, Chichester, UK.

Finton, A. D. 1998. Succession and plant community development in pitch pine-scrub oak barrens of the glaciated northeast United States. Thesis. University of Massachusetts, Amherst, Massachusetts, USA.

Fletcher, P. C. 1993. Soil survey of Barnstable County, Massachusetts. United States Department of Agriculture Soil Conservation Service, Washington, D.C., USA.

Forman, R. T. T. 1979. Pine barrens: ecosystem and landscape. Academic Press, New York, New York, USA.

Foster, D. R., J. D. Aber, J. M. Melillo, R. D. Bowden, and F. A. Bazzaz. 1997. Forest response to disturbance and anthropogenic stress. BioScience 47(7):437-445.
Foster, D. R., D. H. Knight, and J. F. Franklin. 1998a. Landscape patterns and legacies resulting from large, infrequent forest disturbances. Ecosystems 1:497-510.

Foster, D. R., and G. Motzkin. 1999. Historical influences on the landscape of Martha's Vineyard: perspectives on the management of the Manuel F. Correllus State Forest. Harvard Forest Paper Number 23.

Foster, D. R., G. Motzkin, B. Hall, S. Barry Musielwicz, S. Clayden, and T. Parshall. 2002. Cultural, environmental, and historical controls of vegetation patterns and the modern conservation setting on the island of Martha's Vineyard, U.S.A. Journal of Biogeography 29:1381-1400.

Foster, D. R., G. Motzkin, and B. Slater. 1998b. Land-use history as long-term broad-scale disturbance: regional forest dynamics in central New England. Ecosystems 1:96119.

Fuller, J. L., D. R. Foster, J. S. McLachlan, and N. Drake. 1998. Impact of human activity on regional forest composition and dynamics in central New England. Ecosystems 1:76-95.

Grimm, E. C. 1987. Coniss: a Fortran 77 program for stratigraphically constrained cluster analysis by the method of incremental sum of squares. Computers and Geoscience 13: $13-35$.

Grumet, R. S. 1995. Historic contact: Indian people and colonists in today's northeastern United States in the sixteenth and eighteenth centuries. University of Oklahoma Press, Norman, Oklahoma, USA.

Hall, B., G. Motzkin, D. Foster, M. Syfert, and J. Burk. 2002. Three hundred years of forest and land-use change in Massachusetts, USA. Journal of Biogeography 29:1319-1335.

Hough, F. B. 1882. Report on Forestry. Volume 3. U.S. Government Printing Office, Washington, D.C., USA.

Jackson, S. T. 1990. Pollen source area and representation in small lakes of the northeastern United States. Review of Palaeobotany and Palynology 63:53-76.

Jackson, S. T., and P. W. Dunwiddie. 1992. Pollen dispersal and representation on an offshore island. New Phytologist 122: $187-202$.

Jackson, S. T., and M. E. Lyford. 1999. Pollen dispersal models in Quaternary plant ecology: assumptions, parameters, and prescriptions. Botanical Review 65(1):39-75.

Kittredge, H. C. 1968. Cape Cod: its history and their people. Houghton Mifflin, Boston, Massachusetts, USA.

Little, E. A., and M. J. Schoeninger. 1995. The Late Woodland diet on Nantucket Island and the problem of maize in coastal New England. American Antiquity 60:351-368.

Little, S. 1979. Fire and plant succession in the New Jersey Pine Barrens. Pages 297-314 in R. T. T. Forman, editor. Pine Barrens: ecosystem and landscape. Academic Press, New York, New York, USA.

Little, S., and P. W. Garrett. 1990. Pinus rigida Mill. Pages 456-462 in R. M. Burns and B. H. Honkala, editors. Silvics of North America. Conifers. Volume 1. USDA Forest Service, Washington, D.C., USA.

Maenza-Gmelch, T. E. 1997. Holocene vegetation, climate, and fire history of the Hudson Highlands, southeastern New York, USA. Holocene 7(1):25-37.

Mahlstedt, T. 1987. Prehistoric overview. Pages 17-53 in Historic and archaeological resources of Cape Cod and the Islands. Massachusetts Historical Commission, Boston, Massachusetts, USA.

Massachusetts Archives. 1830. 1830 map series. Massachusetts Archives, Boston, Massachusetts, USA.

MassGIS. 1991. MassGIS datalayer descriptions and a guide to user services. Executive Office of Environmental Affairs, Environmental Data Center, Boston, Massachusetts, USA.

McManamon, F. P. 1984. Chapters in the archaeology of Cape Cod I: results of the Cape Cod National Seashore archae- 
ological survey 1979-1981. Division of Cultural Resources, North Atlantic Regional Office, National Park Service, Boston, Massachusetts, USA.

Motzkin, G., R. Eberhardt, B. Hall, D. R. Foster, J. Harrod, and D. MacDonald. 2002. Variation in vegetation across Cape Cod, Massachusetts: environmental and historical determinants. Journal of Biogeography 29:1439-1454.

Motzkin, G., W. A. Patterson III, and N. E. R. Drake. 1993. Fire history and vegetation dynamics of a Chamaecyparis thyoides wetland on Cape Cod, Massachusettes. Journal of Ecology 81:391-402.

Motzkin, G., W. A. Patterson III, and D. R. Foster. 1999. A historical perspective on pitch pine-scrub oak communities in the Connecticut Valley of Massachusetts. Ecosystems 2: 255-273.

Ogden, J. G., III. 1961. Forest history of Martha's Vineyard, Massachusettes I. modern and pre-Colonial forests. American Midland Naturalist 66(2):417-430.

Oldale, R. N., and R. A. Barlow. 1986. Geologic map of Cape Cod and the Islands, Massachusetts. Reston, Virginia, USA.

Olsvig, L. S., J. F. Cryan, and R. H. Whittaker. 1979. Vegetational gradients of the pine plains and barrens of Long Island, New York. Pages 265-282 in R. T. T. Forman, editor. Pine Barrens: ecosystem and landscape. Academic Press, New York, New York, USA.

Parshall, T., and D. R. Foster. 2002. Fire in the New England landscape: regional and temporal variation; cultural and environmental controls. Journal of Biogeography 29:13051317.

Patterson, W. A., III, and A. E. Backman. 1988. Fire and disease history of forests. Pages 603-632 in B. Huntley and T. Webb III, editors. Vegetation history. Kluwer Academic, Dordrecht, The Netherlands.

Patterson, W. A., III, and K. E. Sassaman. 1988. Indian fires in the prehistory of New England. Pages 107-135 in G. P. Nicholas, editor. Holocene human ecology in northeastern North America. Plenum, New York, New York, USA.

Patterson, W. A., III, K. E. Saunders, and L. J. Horton. 1984. Fire regimes of Cape Cod National Seashore. U.S. Department of the Interior, National Park Service Office of Scientific Programs, Report OSS 83-1.

Pickett, S. T. A., and P. S. White, editors. 1985. The ecology of natural disturbance and patch dynamics. Academic Press, Orlando, Florida, USA.

Prentice, I. C. 1985. Pollen representation, source area, and basin size: toward a unified theory of pollen analysis. Quaternary Research 23:76-86.

Pyne, S. J. 1982. Fire in America: a cultural history of wildland and rural fire. University of Washington Press, Seattle, Washington, USA.

Pyne, S. J., P. L. Andrews, and R. D. Laven. 1996. Introduction to wildland fire. Second edition. John Wiley and Sons, New York, New York, USA.

Rose, N. L., S. Harlock, P. G. Appleby, and R. W. Battarbee. 1995. Dating of recent lake sediments in the United Kingdom and Ireland using spheroidal carbonaceous particles (SCP) concentration profiles. Holocene 5(3):328-335.

Russell, E. W. B. 1983. Indian-set fires in the forests of the northeastern United States. Ecology 64:78-88.

Russell, E. W. B., R. B. Davis, R. S. Anderson, T. E. Rhodes, and D. S. Anderson. 1993. Recent centuries of vegetational change in the glaciated north-eastern United States. Journal of Ecology 81:647-664.

Shuman, B., J. Bravo, J. Kaye, J. A. Lynch, P. Newby, and T. Webb. 2001. Late Quaternary water-level variations and vegetation history at Crooked Pond, southeastern Massachusetts. Quaternary Research 56(3):401-410.
Stott, P. 1987. Economic development. Pages 225-322 in Historic and archaeological resources of Cape Cod and the Islands. Massachusetts Historical Commission, Boston, Massachusetts, USA.

Stuiver, M., and P. J. Reimer. 1993. Extended C-14 data-base and revised CALIB 3.0 C-14 age calibration program. Radiocarbon 35(1):215-230.

Stuiver, M., P. J. Reimer, E. Bard, J. W. Beck, G. S. Burr, K. A. Hughen, B. Kromer, F. G. McCormac, J.v.d. Plicht, and M. Spurk. 1998. INTCAL98 radiocarbon age calibration 24,000-0 cal BP. Radiocarbon 40:1041-1083.

Sugita, S. 1993. A model of pollen source area for an entire lake surface. Quaternary Research 39:239-244.

Sugita, S. 1994. Pollen representation of vegetation in Quaternary sediments: theory and method in patchy vegetation. Journal of Ecology 82:881-897.

Sugita, S., G. M. MacDonald, and C. P. S. Larsen. 1997. Reconstruction of fire disturbance and forest succession from fossil pollen in lake sediments: potential and limitations. Pages 387-412 in J. S. Clark, H. Cachier, J. G. Goldammer, and B. Stocks, editors. Sediment records of biomass burning and global change. Springer-Verlag, Berlin, Germany.

Swetnam, T. W., C. D. Allen, and J. L. Betancourt. 1999. Applied historical ecology: using the past to manage for the future. Ecological Applications 9:1189-1206.

Thoreau, H. D. 1988. Cape Cod. Princeton University Press, Princeton, New Jersey, USA.

Turner, B. L., W. C. Clark, W. R. Kates, J. F. Richards, J. T. Mathews, and W. B. Meyer, editors. 1990. The Earth as transformed by human action. Cambridge University Press, Cambridge, UK.

Tzedakis, P. C. 1992. Effects of soils on the Holocene history of forest communities, Cape Cod, Massachusetts, USA. Geographie Physique et Quaternaire 46(1):113-124.

Uchupi, E., G. S. Giese, D. G. Aubrey, and D.-J. Kim. 1996. The Late Quaternary construction of Cape Cod, Massachusetts: a reconsideration of the W. M. Davis model. Geological Society of America, Boulder, Colorado, USA.

U.S. Coast and Geodetic Survey. 1845-1861. Maps of Cape Cod, Massachusetts. Harvard Forest archives, Petersham, Massachusetts, USA.

Vickery, P. D., and P. W. Dunwiddie. 1997. Grasslands of northeastern North America. Massachusetts Audubon Society, Lincoln, Massachusetts, USA.

Webb, T., III, P. J. Bartlein, S. P. Harrison, and K. H. Anderson. 1993. Vegetation, lake levels, and climate in eastern North America for the past 18,000 years. Pages 415467 in H. E. Wright, J. E. Kutzbach, T. Webb III, W. F. Ruddiman, F. A. Street-Perrott, and P. J. Bartlein, editors. Global climates since the last glacial maximum. University of Minnesota Press, Minneapolis, Minnesota, USA.

Westveld, M., et al. 1956. Natural forest vegetation zones of New England. Journal of Forestry 54:332-338.

Whelan, R. J. 1995. Ecology of fire. University of Cambridge, Cambridge, UK.

White, M. A., and D. J. Mladenoff. 1994. Old-growth forest landscape transitions from pre-European settlement to present. Landscape Ecology 9(3):191-205.

Whitney, G. G. 1994. From coastal wilderness to fruited plain. Cambridge University Press, Cambridge, UK.

Williams, M. 1989. Americans and their forests: a historical geography. Cambridge University Press, Cambridge, UK.

Winkler, M. G. 1985. A 12,000-year history of vegetation and climate for Cape Cod, Massachusetts. Quaternary Research 23:301-312.

Winkler, M. G. 1997. Late Quaternary climate, fire, and vegetation dynamics. Pages 329-346 in J. S. Clark, H. Cachier, J. G. Goldammer, and B. Stocks, editors. Sediment records of biomass burning and global change. NATO ASI Series, Volume I. Springer-Verlag, Berlin Heidelberg, Germany. 